\title{
COMPLEX GRAVITY ZONES AND THE EXTENSION OF LABOUR CATCHMENT AREAS IN NORTH TRANSDANUBIA
}

\author{
Dr. Tamás Hardi, Dr. Irén Szörényiné Kukorelli
}

Institute for Regional Studies of Hungarian Academy of Sciences, Centre for Economic and Regional Studies

Liszt F. u. 10, H-9000 Győr, Hungary

e-mail:hardit@rkk.hu, sziren@rkk.hu

Original scientific article

COBISS 1.01

DOI: $10.4312 /$ dela.42.5.95-114

\begin{abstract}
The goals of this study are the identification of the centres of gravity of the NorthernTransdanubian cities, including Győr, by using a gravitation model and, based on empirical examination, the definition of manpower catchment areas. Then, we are going to analyze the impact fields determined by two methods and seek explanations for the overlaps and differences of the two delineations, which are also going to be analyzed with the consideration of geographic, social and economic factors. Both examinations were carried out at two dates, covering a timeframe of 10 years.
\end{abstract}

Key words: Reilly's gravity model, extension of gravity zones, catchment area, commuting area, Transdanubia, Hungary

\section{KOMPLEKSNA GRAVITACIJSKA OBMOČJA IN OBSEG MIGRACIJSKIH OBMOČIJ DELOVNE SILE V SEVERNI TRANSDANUBIJI, MADŽARSKA}

\section{Izvleček}

Namena študije sta identifikacija gravitacijskih središč v severni Transdanubiji (vključno z Györom) z uporabo gravitacijskega modela in, na osnovi empiričnega preučevanja, opredelitev rezervoarjev delovne sile. $\mathrm{Z}$ dvema metodama smo analizirali vplivna območja ter poskušali pojasniti dobljena prekrivanja in razlike, te pa smo nadalje razčlenili ob upoštevanju geografskih, socialnih in ekonomskih dejavnikov. Oba načina preučevanja smo opravili v dveh časovnih presekih, med katerima je deset let razlike.

Ključne besede: Reillyjev gravitacijski model, gravitacijsko območje, migracijsko območje delovne sile, dnevne migracije, območje dnevne migracije, Transdanubija, Madžarska 


\section{INTRODUCTION}

The research area in our survey, North Transdanubia, covers the north-western part of Hungary (Figure 2), occupying approximately one-fourth of the country's territory. In economic sense this region is home to the most advanced regions of Hungary after the capital city, Budapest and its agglomeration, especially in the area of the two industrial centres, Györ and Székesfehérvár. If we look at the spatial distribution of employment figures in Hungary, we can see that the development level of North Transdanubia is visible even in the employment figures of rural areas (Figure 1).

Figure 1: Share of employees ${ }^{1}$ from the residential population in the settlements of Hungary (2011; in \%)

Slika 1: Delež zaposlenih med stalnim prebivalstvom po naseljih na Madžarskem (2011; v\%)

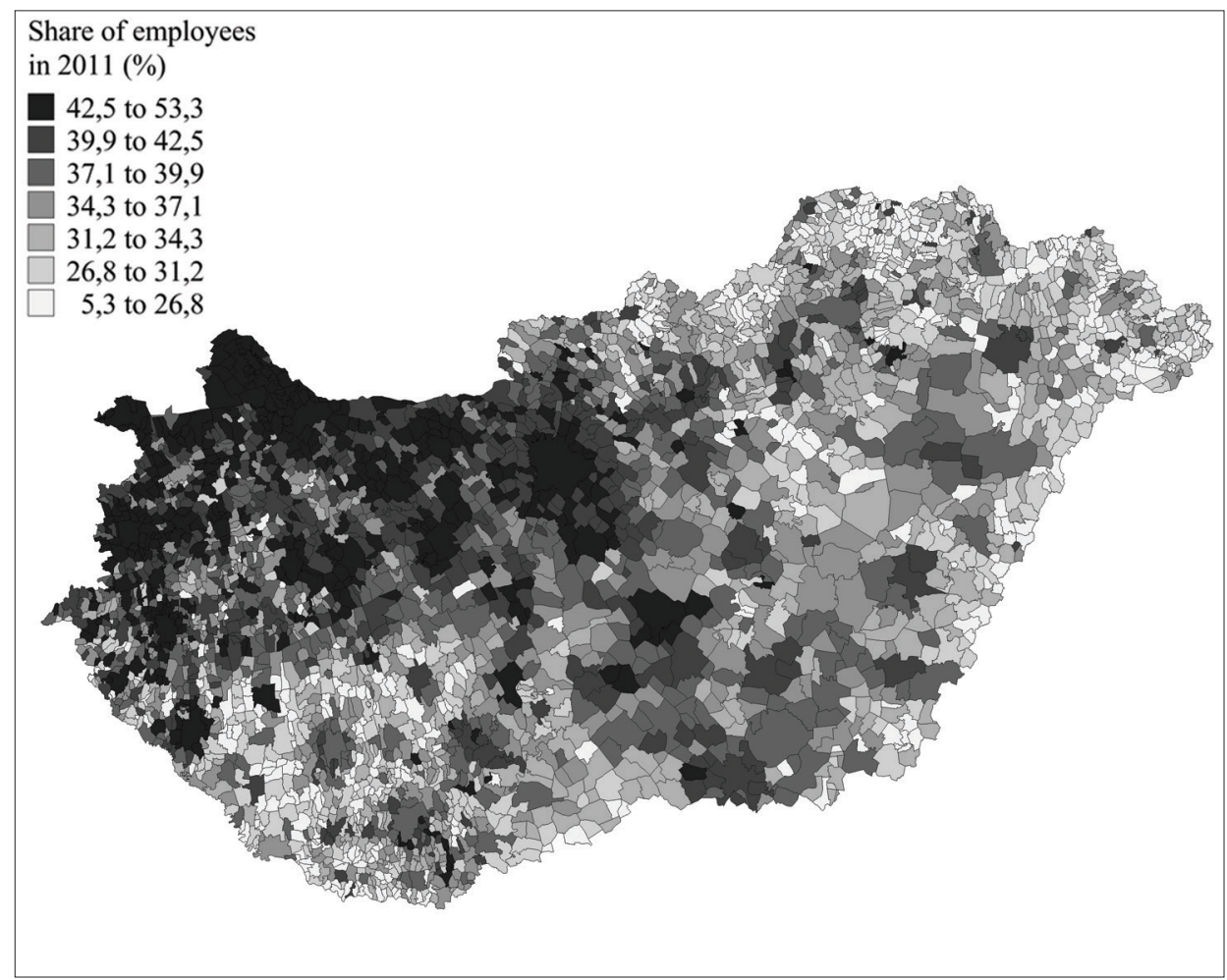

Source/Vir: Calculated and edited by the authors, using the data of the census of 2011

1 According to the definition of the Hungarian Central Statistical Office (HCSO), employees in censuses are all persons aged 15 and over who, in the week before the theoretical date, pursued at least one hour of income generating activity or were only temporarily (e.g. absence due to illness, or paid or unpaid holiday) away from his/her regular occupation (KSH, 2014, pp. 157-160). As we work with census data, this definition is valid in this paper for employees. This may explain differences from figures featured in job centre surveys. 
The number of commuters is rapidly increasing in Hungary, similarly to other European countries. While in 20011.1 million people commuted, their number reached almost 1.4 million by 2011, which is the highest figure in Hungary ever registered in census. In $2001,30 \%$ of earners commuted, in $201135 \%$ of them, which is below the average of the developed European countries (the same figure for Germany is $45 \%$ ). While the increase of income-earning people was $2.8 \%$ between the two times, the growth in the number of commuters reached $26 \%$.

Compared to the other regions of Hungary, the number and proportion of commuters is high in North Transdanubia: $45 \%$ of employees in this region commute, which is the highest among all regions of Hungary. This fact is due not only to the high level of economic development but also the special characteristics of the settlement network. Several urban and employment centres of different sizes have evolved, with small and medium-sized villages among them - as opposed to the Great Hungarian Plain where large settlements can be found next to each other, with smaller volumes of traffic among

Figure 2: Number of in-commuters in the settlements of Hungary, 2011 (persons)

Slika 2: Število prihajajočih dnevnih migrantov po naseljih na Madžarskem (2011)

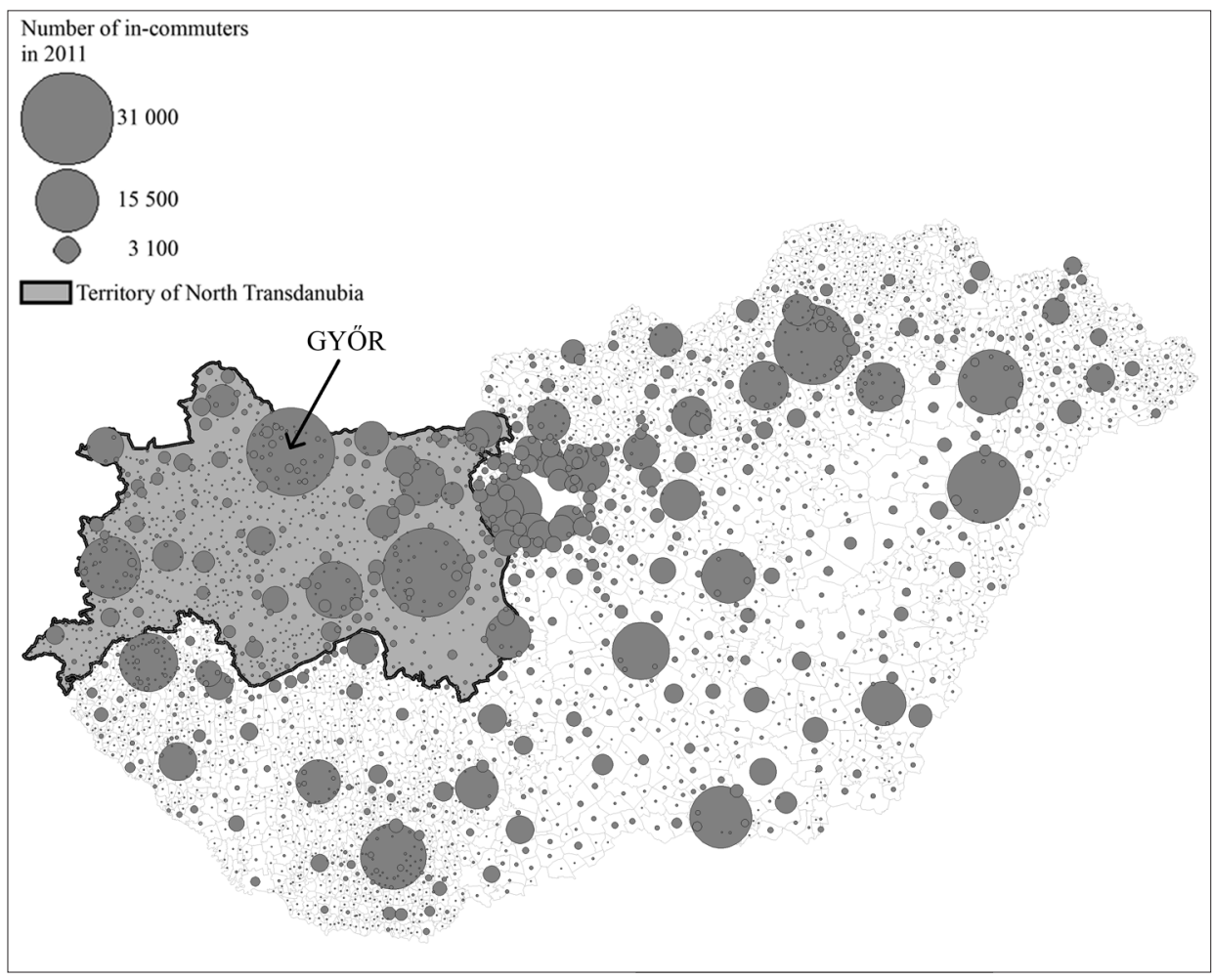

Source/Vir: Calculated and edited by the authors, using data of censuses 
them - or northeastern Hungary and South Transdanubia where the settlement structure is dominated by small villages and a few larger urban centres. In North Transdanubia, on the other hand, a relatively dense settlement network and hierarchy have evolved (Figure 2). The density of the urban network is partly a historical heritage, the outcome of the specific spatial structural development of the region (Györi, 1999).

However, even besides relatively high level of economic development and the dense network of centres there are inner peripheries, declining rural areas where both the number of inhabitants and that of jobs decrease. These areas typically evolve in poorly accessible places far from the centres, and what is worrying is that they make contiguous zones.

Therefore, in our paper we examine how the action spaces, the catchment areas of the centres cover North Transdanubia and how these action spaces have changed in a decade. This is examined first by a theoretical tool, a gravity model, and then compared to the empirical analysis of the censuses of 2001 and 2011. On the ground of these findings we look at how the situation and action spaces of the centres have changed in the early 21 st century.

For the definition of the action space we used a modified version of Reilly's gravity model where the weight was a calculated (complex) index. While Reilly's gravity model always designates gravity zones between two points (cities), in our model we defined the gravity zones of 31 settlements in North Transdanubia for two dates simultaneously. This also allowed the comparisons of the changes of gravity zones during ten years period.

The second part of the paper introduces the spatial change of the phenomenon of commuting in North Transdanubia ${ }^{2}$, highlighting the role of Györ and its hinterland within the region of North Transdanubia.

\section{GRAVITY MODEL FOR THE TOWNS AND CITIES OF NORTH TRANSDANUBIA}

The use of gravity model aims at the examination of different spatial interactions. Interactions in space mean forms of movements among people, including most frequently trip to work (commuting), the use of public services, retail services, and the connections between tourism destinations and the place of residence. Many cases indicate that gravity model is suitable for the examination of migration processes, the movement of capital and information, and the demand and supply flows necessary for the economic activities (Greenwood, 2005). As these processes are related to overcoming spatial distances, there must be a demand and supply relation between places connected to each other, which can be measured by distance, and the time function coming from the development level of transport infrastructure, and so the use of gravity model is often related to transport geography and the planning of transportation as well (Erlander, Stewart, 1990).

The question is how gravity spaces can be designated and how they change, with what conditions. The amendment of the parameters may change the gravity zone, and

2 North Transdanubia consists of five counties: Fejér, Győr-Moson-Sopron, Komárom-Esztergom, Veszprém and Vas. 
if we also have empirical data, we can simulate the spaces of gravity by comparison of the model and the empirical findings; in fact, the selection of the right parameters may even assist the forecast of gravity spaces generated by certain processes (Rodrigue, 2013).

The survey of the catchment areas of cities is usually done by using the gravity model published by Reilly (1929), according to which the borderline (geometrical place) of the gravity zone between two points (settlements) is defined by the number of population in direct proportion and the square of the distance in inverse proportion. In the 1960s and 1970s, Hungarian geographers also used this method for the designation of retail trade catchment areas (Beluszky, 1966). Papp made complex index from nine indicators and used it as a weight in the work on the designation of the hinterland of Debrecen (Matematikai ..., 1984). In the 1990s, the modified version of Reilly's gravity model was used for the examination of retail trade related movements within the city of Györ (Nagy, 1996). The weight of the city districts was given by the revenues in the first case, followed by base area of retail facilities in the second case, and the base area and the population in the third case. In all three cases, distance was defined by a time function determined by public transportation.

In the attempt below we defined the gravity spaces of 31 settlements in North Transdanubia, using Reilly's model. As the paper also focuses on the empirical survey of the labour catchment areas, we selected from the settlements of the region those with a substantial number of jobs for their size and many of these jobs are occupied by in-commuters. The experiments mentioned above were used for setting up a complex modified model. The gravity weight is given, instead of the number of population, by a complex index as follows:

$$
\mathrm{S}_{\mathrm{i}}=\mathrm{N}_{\mathrm{i}} * \sum_{\mathrm{k}=1}^{\mathrm{m}} \sqrt{\frac{\alpha_{\mathrm{k}, \mathrm{i}}}{\overline{\alpha_{\mathrm{k}}}}}
$$

where

$\mathrm{N}_{\mathrm{i}} \quad$ number of people employed in the settlement

$\mathrm{m} \quad$ variables (number of attributes)

$\alpha_{k, i} \quad$ value of attribute ' $k$ ' of settlement ' $i$ ' $\left(\alpha_{k, i} \geq 0\right)$

$\alpha_{\mathrm{k}} \quad$ mean of attribute ' $\mathrm{k}$ '

This way the weight of the given settlement is defined by the number of employees in the settlement multiplied by the total of the square roots of the relative values of the respective indicators. The use of these square roots is worthwhile as this can lessen the dominating effect of the settlements with outstanding weights. During the preliminary experiments it became clear that the relative value of indicator had to be used, only, this would have made the gravity spaces of larger centres, especially of Györ 'borderless'. This made us to modify the weight and calculate the square roots of the relative value of the indicator. 
Another novelty compared to the gravity models applied earlier is that the borderline separating the gravity spaces of two settlements in Reilly's model was calculated in this instance for 31 settlements at the same time. Feeding-in the geo-coordinates of the towns and $\operatorname{cities}^{3}$, the borders of the gravity zones were defined as follows:

$$
\mathrm{F}_{\mathrm{i}}=\frac{\mathrm{S}_{\mathrm{i}}}{\ln (r)}, \mathrm{r}=\sqrt{\left(\mathrm{GeoX}_{\mathrm{i}}-\mathrm{GeoX}_{0}\right)+\left(\mathrm{GeoY}_{\mathrm{i}}-\mathrm{GeoY}_{0}\right)}
$$

where

$F_{i}$ is the attraction of centre' $i$ ', $F_{j}$ is the attraction of centre ' $j$ ', and any other geographical point $\left(\mathrm{GeoX}_{0}\right.$; $\left.\mathrm{GeoY}_{0}\right)$ belongs to the gravity zone of centre ' $\mathrm{i}$ ' if $\mathrm{F}_{\mathrm{i}}>\mathrm{F}_{\mathrm{j}}$ in all cases where $\mathrm{i} \neq \mathrm{j}$.

Variables used for the complex index for the settlements included in the examination were taken from the 2002 and 2012 databases of TEIR (Országos Területfejlesztési és Területrendezési Információs Rendszer; National Information System of Regional Development and Spatial Planning; http://www.teir.hu), except for the last two figures that are only included in the census data every tenth year. The variables used for the definition of the weights of the settlements were as follows:

- Number of registered businesses;

- Number of beds in all commercial accommodations;

- Number of overnight stays at commercial accommodations;

- Total number of freight vehicles (including vehicles for special use);

- Total number of hospital beds in use;

- Number of visitors to museums;

- Number of visitors to theatres;

- Number or secondary school students in full time training (including vocational training);

- Number of in-commuters - data of the censuses of 2001 and 2011;

- Number of inhabitants employed - data of the censuses of 2001 and 2011. ${ }^{5}$

The method above was used for the definition of the gravity zones of 31 towns and cities in North Transdanubia and also the gravity power lines that refer to the intensity of the gravity, as the closer they are to the centre, the more intensive gravity is (Figures 3 and 4). The figures of gravity done for both dates (2002-2012) do not show many differences, the gravity spaces of the respective settlements did hardly change. The reasons for the changes are explained later.

The extension of gravity zones reflect the size of the towns and cities, so at the first glance we can see no surprising results, as Györ has the most extended space of gravity,

3 www.futas.net/gps/geo.php

4 Number of in-commuters: number of people commuting to the settlement from other settlements

5 Number of employees: people qualified as employees from the total population of the respective settlement 
followed by Székesfehérvár, Szombathely and Veszprém. The total of 31 settlements can be categorised into four groups on the basis of the size of their gravity zones.

Group 1 is made of big cities, Győr, Székesfehérvár, Veszprém, Szombathely, Sopron, Tatabánya and Esztergom. As for the calculation of the weight we also included cultural and educational indices, the gravity zone of big cities must reach beyond their labour catchment area. It is clear that the gravity zone of Györ stretches southwards right to the Lake Balaton, although this gravity zone is limited by Veszprém and Székesfehérvár on the southeast. In the direction of Pápa, on the other hand, there are no cities significant enough to close the gravity space of Györ. Comparing the maps of 2002 and 2012 we can see practically no changes in the gravity zones of the cities in this category, but their weights did change. The weight of Győr, Sopron and Tatabánya increased, that of the other settlements decreased, which is especially striking at Veszprém, as its weight in 2012 was only $89 \%$ of that in 2002. Due to this loss of weight Veszprém and Szombathely changed positions, parallel to the loss of importance in the latter city as well. The order in 2012 looked as follows: Györ, Székesfehérvár, Szombathely, Veszprém, Tatabánya and Esztergom.

Group 2: This category involves those small and medium-sized towns whose zones of gravity rip their catchment areas off the space of a big city from Group 1. Members of this group are Tapolca, Ajka, Pápa, Sárvár, Komárom and Mosonmagyaróvár. Some of them also divert the catchment area of one another, i.e. they collide like the gravity zones of Tapolca, Ajka and Pápa, towns that cut-off parts of the catchment areas of Györ and Veszprém, anyway, and there are towns like Mosonmagyaróvár and Sárvár that are embedded into the larger gravity zones of big cities. Komárom cuts into the hinterland of Győr and Tatabánya, ripping off its own space of gravity. These middle sized towns, with the exception of Ajka, make a dynamic group. Sárvár, Komárom and Mosonmagyaróvár significantly increased their importance in 10 years, improving their positions since 2002, while Ajka fell from position 11 to position 13 . The space of gravity of these three towns visibly grew in ten years.

Group 3 is the group of settlements with small spaces of gravity, do not divert the gravity power lines of the big cities embedding them, and they only occupy smaller gravity spaces within those of the larger centres. These towns are the following: Kapuvár, Csorna, Kőszeg, Bük, Körmend, Sümeg, Balatonfüred, Zirc, Várpalota, Mór, Kisbér and Bicske. Seven of the 12 settlements increased their weight since 2002: Bük, Balatonfüred, Zirc, Várpalota, Mór, Kisbér and Bicske. The growth in the weight in itself was not a guarantee of better position in the ranking, as Balatonfüred and Bük lost two positions each, despite their weights that increased since 2002, and the same happened in the case of Zirc and Várpalota. The growth of the weight of these two small towns, as in the case of Sárvár in the previous group, is due to the indicators of tourism, which of course also contributed to the increase of the number of employees and in-commuters.

Group 4 involves those settlements whose gravity zones are actually points in space, only, i.e. hardly reach beyond the boundaries of the settlement. Towns in this group are Fertőszentmiklós, Beled, Jánossomorja, Mosonszolnok, Vasvár and Tét. These settlements, with the exception of Vasvár, are all young towns; in fact, Mosonszolnok does not even have a town status. With the exception of Vasvár, they are small but dynamic industrial centres, with considerable numbers of jobs and in-commuters. The weights of 
these settlements increased much more significantly in ten years than the similar figures of settlements in the former groups did. Within the 31 settlements, the weight ratio of Mosonszolnok is 1.78, that of Fertöszentmiklós and Jánossomorja 1.32, of Beled 1.27, which is evidently due to the intensification of in-commuting induced by the increased number of industrial jobs over the last ten years. Their space of gravity is small, as the values of other indicators making the weight are low, and they have hardly any touristic, public service, public education or cultural attraction for their areas.

Figure 3: Extension of the complex spaces of gravity in 2002

Slika 3: Kompleksna gravitacijska območja leta 2002

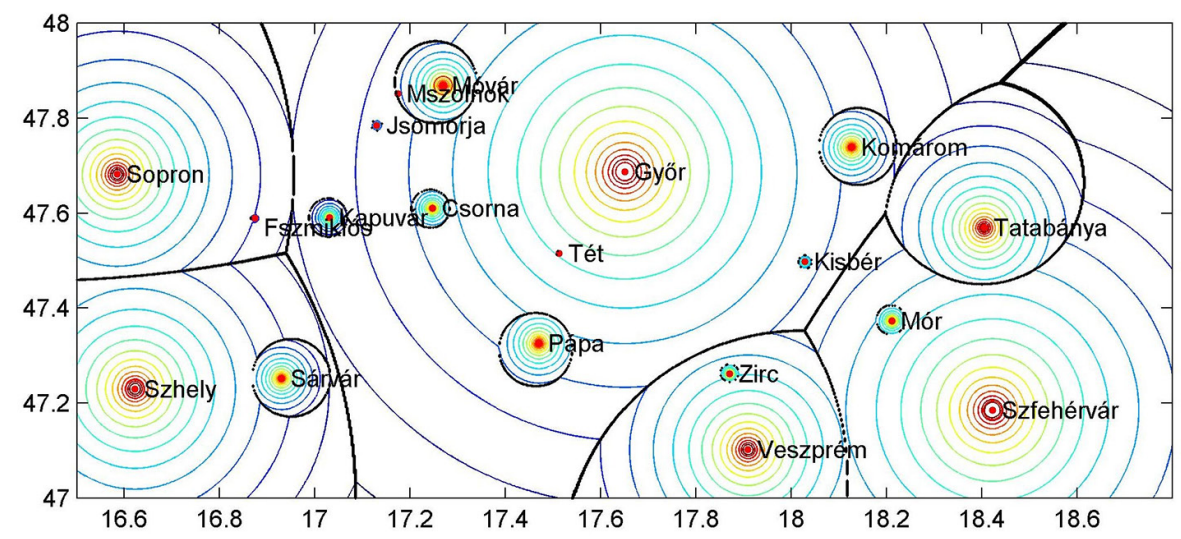

Source/Vir: Calculations by the authors (applying the Matlab software, with the contribution of Dr. Miklós Szörényi)

Figure 4: Extension of the complex spaces of gravity in 2012

Slika 4: Kompleksna gravitacijska območja leta 2011

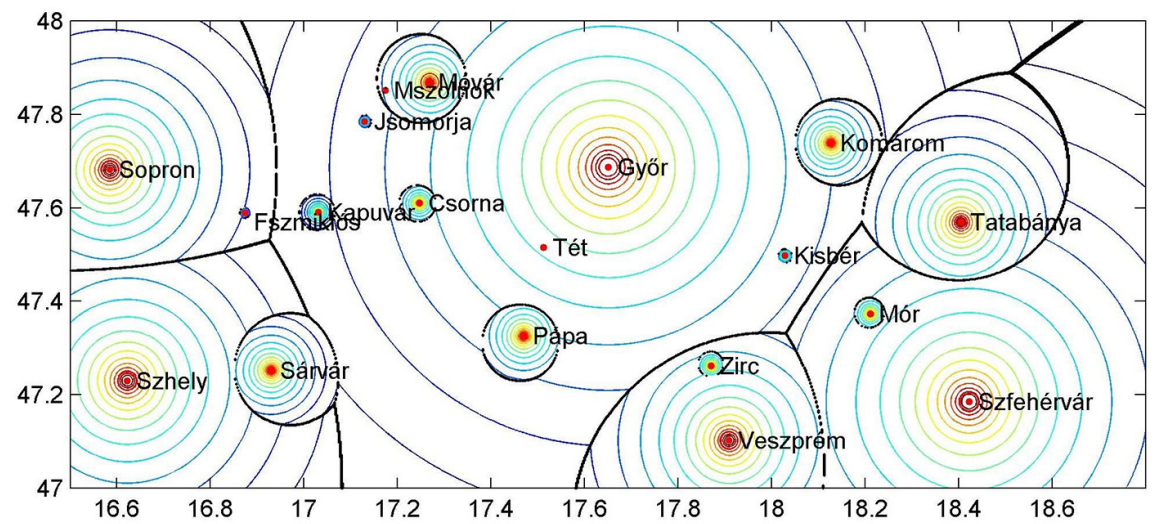

Source/Vir: Calculations by the authors (applying the Matlab software, with the contribution of Dr. Miklós Szörényi) 
As the further goal of the paper is the examination of the labour catchment area, we simplified the model after the definition of the complex gravity space and only used indicators related to commuting (number of registered businesses, in-commuters and employees) for the designation of the gravity zones of the centres for both dates (Figures 5 and 6).

Figure 5: The gravity zones of movements of labour force in 2002

Slika 5: Gravitacijska območja migracij delovne sile v letu 2002

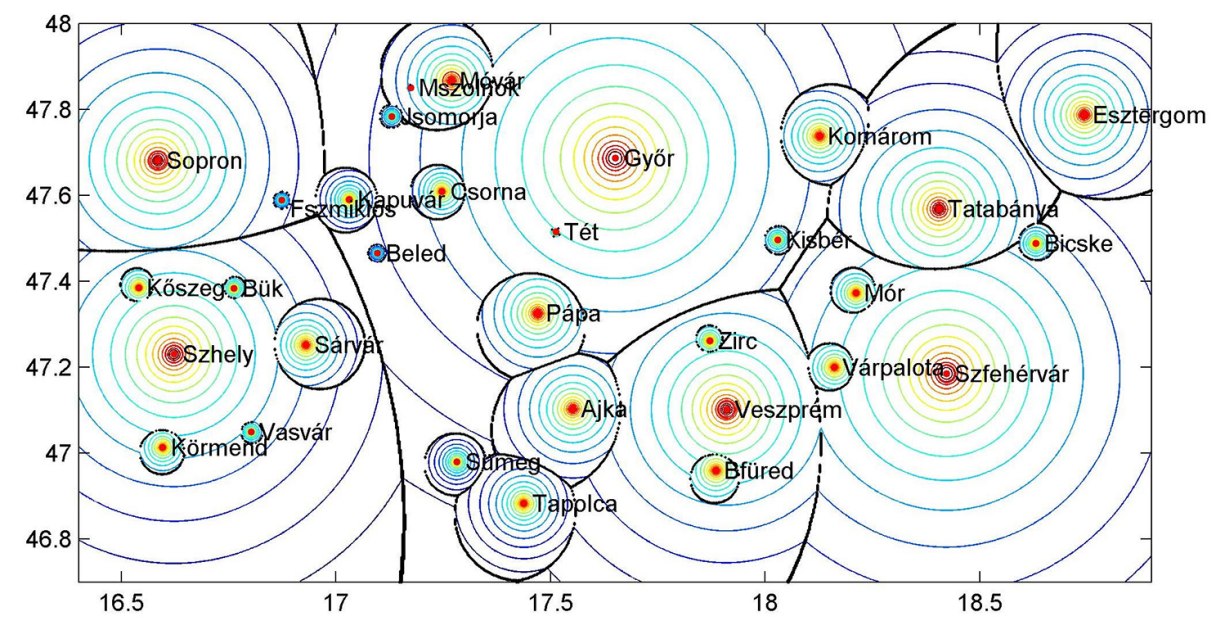

Source/Vir: Calculations by the authors (applying the Matlab software, with the contribution of Dr. Miklós Szörényi)

Figure 6: The gravity zones of movements of labour force in 2012

Slika 6: Gravitacijska območja migracij delovne sile v letu 2012

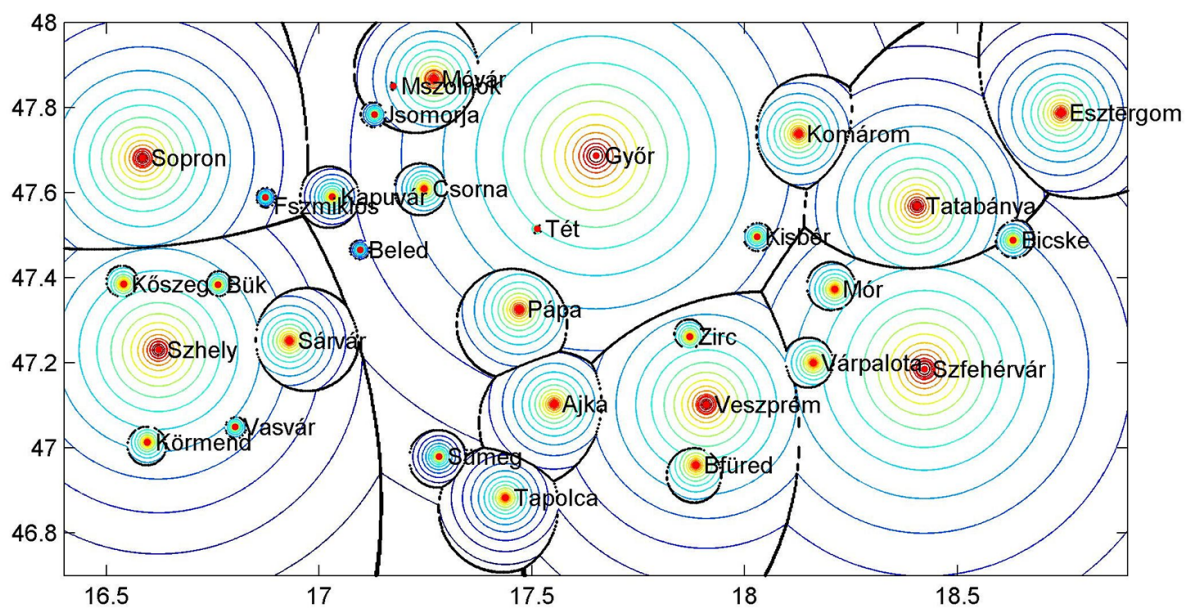

Source/Vir: Calculations by the authors (applying the Matlab software, with the contribution of Dr. Miklós Szörényi) 
By overlapping figures 3 and 5 and 4 and 6, the change of the complex and the labour gravity zones can be followed.

Comparing the complex and the reduced weights, the towns and cities in our survey can be classified into four groups on the ground of the change of the weight between the two times.

Table 1: Transitions of the weights between 2002 and 2012

Preglednica 1: Spremembe gravitacijske privlačnosti med leti 2002 in 2012

\begin{tabular}{|l|l|l|l|}
\hline $\begin{array}{l}\text { Both complex and } \\
\text { reduced weight } \\
\text { increased }\end{array}$ & $\begin{array}{l}\text { Both complex and } \\
\text { reduced weight } \\
\text { decreased }\end{array}$ & $\begin{array}{l}\text { Only complex weight } \\
\text { increased }\end{array}$ & $\begin{array}{l}\text { Only reduced weight } \\
\text { increased }\end{array}$ \\
\hline Pápa & Szombathely & Györ & Zirc \\
\hline Sopron & Veszprém & Csorna & Sárvár \\
\hline Mosonmagyaróvár & Székesfehérvár & Kapuvár & Mór \\
\hline Jánossomorja & Körmend & Esztergom & Várpalota \\
\hline Mosonszolnok & Tapolca & Ajka & \\
\hline Fertószentmiklós & Kőszeg & Vasvár & \\
\hline Tét & Sümeg & & \\
\hline Komárom & & & \\
\hline Kisbér & & & \\
\hline Tatabánya & & & \\
\hline Bicske & & & \\
\hline Balatonfüred & & & \\
\hline Bük & & & \\
\hline Beled & & & \\
\hline
\end{tabular}

Source/Vir: Calculations by the authors

The comparison of the figures of Reilly's gravity model calculated with two weights (Figures 4 and 6) clearly demonstrates that there is no substantial difference between the boundaries of the zones of gravity, which implies that in gravity effect it is the number of employees, the number of businesses and the number of in-commuters that matter the most from among the nine variables. This dominance is well indicated by the groups of settlements categorised into four types (Table 1). In those young towns with a small population that became significant employment centres during these 10 years, primarily due to their industrial jobs, the three indices used for the calculation of the reduced weight are so dominant also in the case of their complex weights that they increase the complex weight as well. In settlements where both values decreased, partly the urban functions and partly employment functions too may have weakened, e.g. in the first case the values of tourism related indices, in the second case the number of in-commuters may have decreased or 
both may have contributed to the decline in the weight simultaneously. The settlements in Group 4 typically reached their complex weights in these 10 years by the enhancement of their other urban functions, parallel to their declining employment indices.

The gravity spaces of the examined towns and cities show only minor changes in one decade. The North Transdanubian region falls into the gravity zones of four big cities, which are diverted by the gravity zones of smaller settlements, or the latter rip off areas from the larger spaces of gravity. The gravity spaces of four towns - Tapolca, Sümeg, Ajka and Pápa - collide into each other, while all other small towns only occupy their spaces of gravity within the spaces of the dominant big cities. The gravity zone of Györ embeds Mosonmagyaróvár, Jánossomorja, Kapuvár, Csorna, Beled, Tét and Kisbér, while the gravity of Szombathely reaches to Sárvár, Bük, Körmend and Vasvár, each of which rip off a separate action space from the space of the big city. The spatial division that shows the biggest change in the ten years is striking in the case of the small towns. Towns that significantly increased their zones of gravity are Komárom, Mosonmagyaróvár and Sárvár, while some of the big cities - Veszprém and Székesfehérvár - have somewhat smaller spaces of gravity now. Györ slightly increased the extension of its space of gravity. The expansion of the gravity zones of the towns and cities in our survey is mostly influenced by the gravity zones of the labour force, i.e. there is significant similarity between them.

\section{COMMUTING IN NORTH TRANSDANUBIA}

For the examination of the spatial structure of North Transdanubia and the geographical extensions of the labour catchment areas of urban centres we analysed and compared the data of commuters in the censuses of 2001 and 2011. The places of residence and the workplaces of respondents are known, and so from these data we calculated the number of employees in the respective settlements, as well as the number of out- and in-commuters $^{6}$. Some of our data may differ from the official employment data, as in the censuses those respondents aged over 15 are seen as employees who spent at least one day with income earning activity in the week prior to the survey or were only temporarily away from their regular occupation (KSH, 2014).

Commuting appeared and became a mass phenomenon in Hungary in the 1960s and 1970s. This was the time of the industrialisation of countryside towns, and so these two decades are the dominant decades of Hungarian urbanisation. The development of communal infrastructure could not keep up with the demand of industrial investments for labour force, and so the shortage of homes became an obstacle to moving to towns and

6 We calculated the following variables from the census data:

- Local resident and employed: employee who works in the same settlement as where s/he permanently lives;

- Daily commuter is an employee who does not work in the same settlement where s/he actually lives;

- Number of employees: those in the population of the respective settlement who are qualified as employees;

- Number of people employed locally: the total of employees in the respective settlement who live and work in the settlement, and of in-commuters. For the sake of simplicity this is handled as the number of workplaces. The two concepts are evidently not the same, but they refer to the employment capacity of the settlement;

- Number of out-commuters: number of people commuting from a settlement to another settlement;

- Number of in-commuters: number of people commuting to the settlement from another settlement. 
cities (Konrád-Szelényi, 2000). On the other hand, this period was also an important time in the modernisation of villages in Hungary: agriculture providing relatively high living standards kept the major part of population in place, even those who found employment in industrial plants or the service sector in cities. This increased the significance of 'parallel existence': families kept their village places of residence besides their jobs in the city, and the simultaneously pursued agricultural activity gave them a substantial secondary income. Commuting thus concerned masses of people, and in its character it was built on the village-town relationship. Although the economic crisis around the time of the regime change decreased the chances of commuting to industrial plants in towns and cities, a significant part of jobs were liquidated in villages too; parallel to the transformation of large-scale agricultural holdings, an increased proportion of the rural population had to find employment in towns and cities.

Figure 7 shows the proportion of people employed in their places of residence within the total of the population employed. Evidently, in settlements where this proportion exceeds $100 \%$ there are more workplaces than own residents employed, so in-commuting is intensive. It is striking that these centres stand out from the peripheral regions like is-

Figure 7: People employed locally, in proportion of population employed (2011: in per cent), and the change of this proportion since 2001 (in per cent) by settlements

Slika 7: Razmerje med zaposlenimi v domačem kraju in skupnim številom zaposlenih $(2011 ; v \%)$ ter sprememba razmerja po 2001 ( $v \%$ )

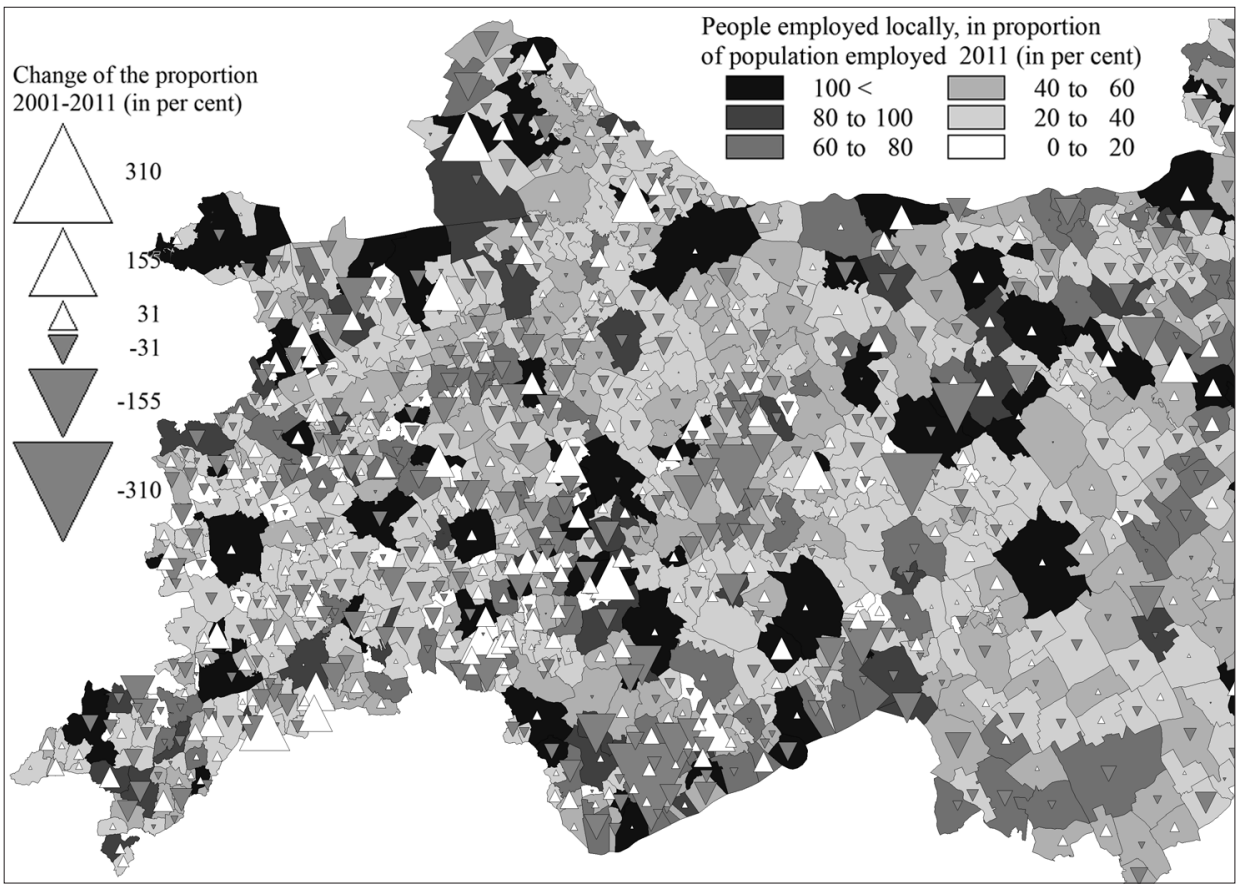

Source/Vir: Calculated and edited by the authors, using the data of censuses 
lands. Our map also demonstrates the change of this proportion between 2001 and 2011 . This shows that around the 'islands' settlements increasing their employment may arise, like the south-eastern and north-western agglomeration stripe of Györ, parallel to the considerable losses of inner peripheries over ten years. These inner peripheries are either far from the agglomeration of Györ or are in poorly accessible locations. Their population can mainly approach smaller centres by daily commuting.

Just for this reason, the number of in-commuters to smaller centres grew as well, even if the number of people employed locally in small centres considerably decreased in the last ten years (Figure 8). This map shows even more clearly those development axes where employment and thus also commuting is concentrated. One such development axis is the line of the motorway M1 starting from the Budapest agglomeration (Budapest-Györ-Vienna), along which there are agglomerations and industrial districts with Tatabánya, Győr and Mosonmagyaróvár as centres. The most significant of these is Győr. The other axis runs across the southern part of the region, along trunk road No 8, organised around Dunaújváros, Székesfehérvár, Veszprém and Ajka cities. Székesfehérvár is the other major countryside commuting centre besides Győr, and although this city lost

Figure 8: Change of locally employed and in-commuting labour force in North Transdanubia between 2001 and 2011 (persons)

Slika 8: Spreminjanje razmerja med zaposlenimi v domačem kraju in dnevnimi migranti v severnem delu Transdanubije med letoma 2001 in 2011 (število oseb)

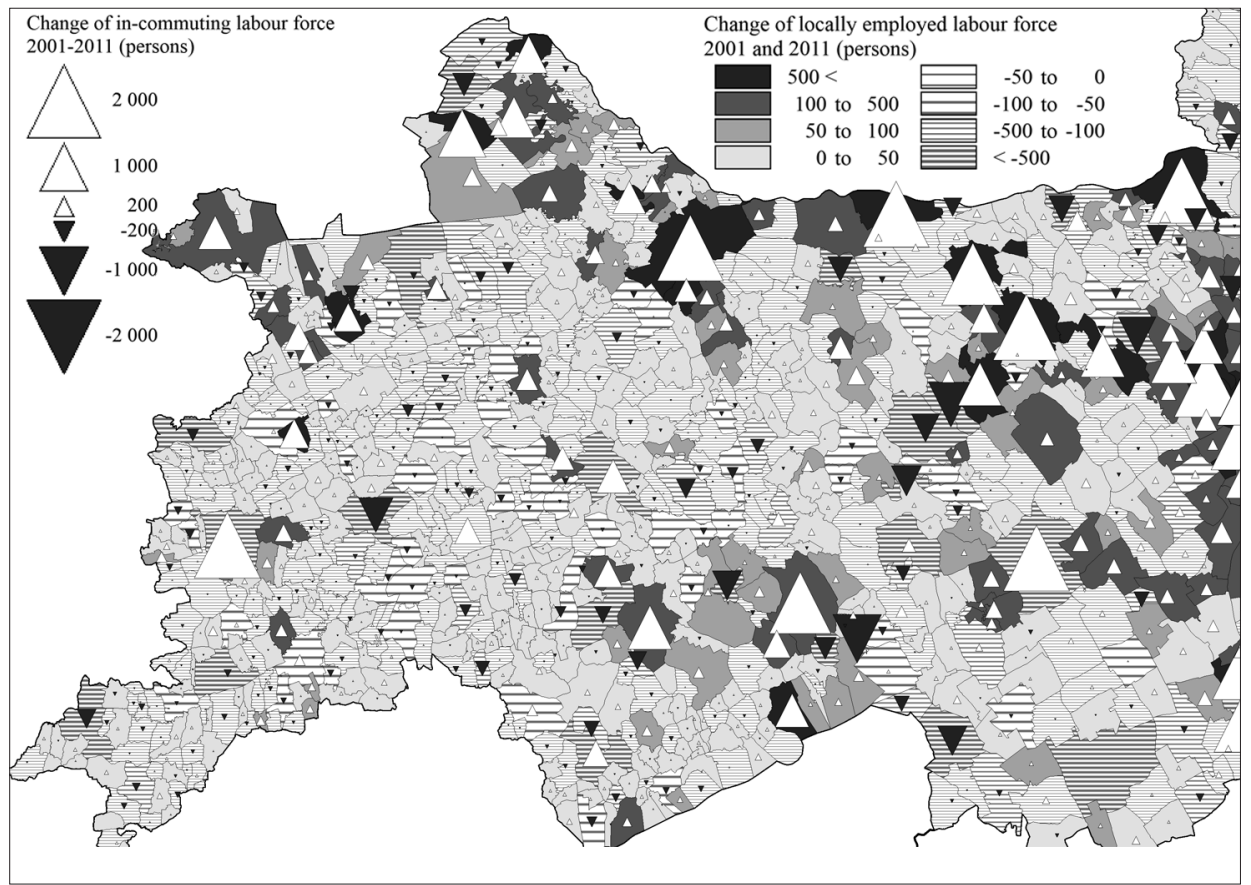

Source/Vir: Calculated and edited by the authors, using the data of censuses 
some of the labour force employed locally, in its agglomeration employment increased in several settlements.

In addition to these two big axes, Sopron and its area is of outstanding significance, whose development is mainly due to its location at the border to Austria and the proximity to the growth axes in Austria.

Among these axes and districts, in the peripheral areas we find several centres of different sizes. A common feature of these settlements is the significant loss of locally employed labour force in ten years. It is an interesting phenomenon that several of these centres still attract a significantly larger number of in-commuters. The explanation for this is the fact that more and more of the employees of these settlements now commute to larger centres (e.g. Győr) or abroad, and the smaller centres gain their labour force from the nearby rural areas that have lost jobs. Typical examples for this are Szombathely and Pápa. Several smaller centres, on the other hand, suffered such a loss that led not only to the decrease in the number of jobs but also a considerable fall in the number of incommuters. These are the small towns with industry which relies primarily on commuting labor force (e.g. Sárvár or Mór).

\section{CENTRES AND THEIR LABOUR MARKET HINTERLANDS IN NORTH TRANSDANUBIA}

Around the centres of North Transdanubia commuting catchment areas can be designated. The respective settlements are ordered to that centre where most of the commuters travel. Slightly supplementing the formerly known methodology (Benini, Naldi, 2007; Salamin, Radvánszky, Nagy, 2008; Pénzes, Molnár, Pálóczi, 2014) and categorising the centres, also including the smaller rural centres in the examination, we defined the centres of North Transdanubia and their independent labour catchment areas (Figures 9-10). The levels can be distinguished by the number of commuters attracted and the sizes of the catchment areas. Two centres can be defined at regional level: Győr and Székesfehérvár. Both cities attract some 30,000 commuters a day and their catchment areas reach well beyond the county borders, touching several counties. In fact, the catchment area of Györ stretches to Slovakia. Besides these two big cities there are county and micro-regional centres (5,000-10,000 commuters), and small and micro-centres (500-5,000 commuters), central settlements that do not have catchment areas of their own but the number of in-commuters from the nearby settlements is significant (Figures 9-10).

If we compare the results calculated from the data of the two censuses, we can see that the extension of the catchment areas of the centres did not change significantly.

1. Around the centres designated by the criteria there are homogenous catchment areas that make a geographically contiguous area.

2. Beyond the contiguous area, another centre is part of the catchment area, with its own catchment area; e.g. Komárom is a small town with a large commuting zone, but the town itself belongs to the catchment area of Györ. Similar connections can be seen in the Sárvár-Szombathely relationship. 
Figures 9-10: Commuting centres of North Transdanubia and their catchment areas in 2001 and 2011

Sliki 9-10: Zaposlitvena središča v severni Transdanubiji in njihova gravitacijska območja v letih 2001 in 2011
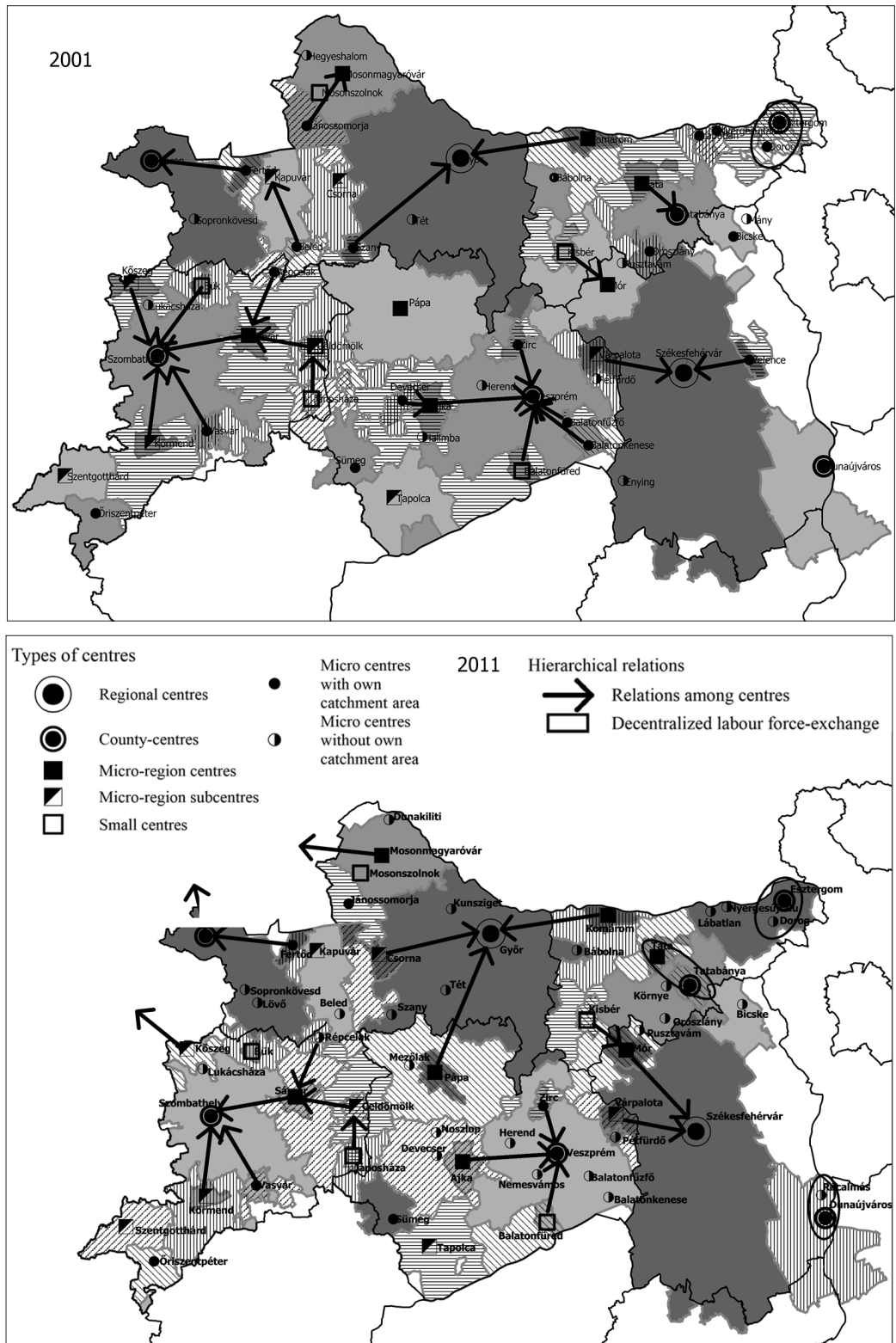

Source/Vir: Calculated and edited by the authors, using the data of censuses 
3. Both within the examined macro-region and outside it, there is relatively little commuting across the county borders. Among the centres of North Transdanubia it is only Györ and Székesfehérvár whose catchment areas reach well beyond the borders of their own counties, and even these cities do not have homogenous catchment areas and attract significant numbers of commuters from lower level centres (Györ from Pápa, while Székesfehérvár from Várpalota). A significant attraction from the outside is asserted by Budapest on settlements of North Transdanubia, involving a larger area in its hinterland from the eastern frontiers of the region, while on the west it is the non-specified settlements of Austria that are primary destinations of commuting from several Hungarian towns and villages. The mutual attraction of labour force from Zala and Somogy counties is limited, while towards Tolna county it is Székesfehérvár and Dunaújváros that stretched out their catchment areas; the latter city also extended its catchment area towards Bács-Kiskun county.

4. In the case of almost all centres, out-migration intensified, often to a considerable extent. This is true for centres where there was an increase in the number of locally employed labour force and also where a decrease occured.

5. The decline in the number of locally employed labour force is not followed everywhere by the decrease in the number of in-commuters. In the case of Pápa e.g., besides a slight decrease in the number of local employment out-migration strengthened considerably, but so did in-migration, too. On the other hand, in other smaller centres, the intensification of out-migration is accompanied by the significant decline in the other two indices (e.g. Mór). What is remarkable about these two types is that major regional centres like Pápa remained important destinations of commuting despite the crisis, as the surrounding settlements are not in a good geographical position that would allow the inhabitants to commute to more distant, larger centres. To the opposite, many smaller employment centres where it was mainly industrial parks that concentrated on simple mobile assembly activities based on in-commuting labour force proved to be vulnerable and suffered a rapid fall in employment in some cases.

6. Some micro-centres ceased to exist as destinations of commuters with their catchment areas of their own, e.g. Bábolna and Jánosháza.

7. On the other hand, micro-centres that do not have catchment areas of their own but are situated in the area, agglomeration of a larger centre strengthened; an example is Mosonszolnok.

8. A number of centres ceased to be 'sovereign'; in 2001 there was no destination for many central settlements to which inhabitants out-commuted in large numbers, whereas in 2011 the population of all commuting centres, with the exception of a few, were attracted by commuting centres at higher level in the hierarchy, e.g. the PápaGyőr or Mór-Székesfehérvár relation.

9. Commuting abroad is more important than it was. While in 2001 it was only Mosonmagyaróvár and Sopron for whose inhabitants the primary destination of commuting was Austria, the neighbour country has become the number one target area for many other centres by now (Jánossomorja, Kapuvár, Fertőd, Köszeg, Szombathely, Szentgotthárd). In addition, several settlements in the vicinity of the border are no longer 
part of the Hungarian catchment areas, as the primary destination for their inhabitants is Austria, or Bratislava in the case of $\mathrm{Rajka}^{7}$.

\section{CONCLUSION}

The paper is about the designation of the gravity zones of 31 settlements of North Transdanubia, using the gravity model of Reilly (1929) for two dates and using two complex indices. While the gravity zones ordered to the complex weight calculated with 9 variables are primarily connected to urban functions, the second gravity model created is only about commuting and employment. The difference between the gravity spaces defined by the two weights is small, and there is no major difference between the two dates, either. At both times and for all weights the largest spaces of gravity in North Transdanubia are those of Győr, Székesfehérvár and Szombathely. Besides them the gravity zones of Sopron, Veszprém and Tatabánya are significant. The gravity zones of the remaining 25 settlements are embedded in the spaces of the above-mentioned big cities, either in their entirety or falling into the puffer zone of two large settlements.

We examined the spatial consequences of the disparities between the major data of the censuses made by the Hungarian Central Statistical Office in 2001 and 2011 related to commuting (number of commuting employees by places of residence and target settlements). In addition to the national level surveys, we concentrated on North Transdanubia whose centres were analysed in details. Even more attention was paid to Györ and the characteristics of the space around this city. Although it is natural that the model and the designation of catchment areas using empirical data cannot overlap, during the analysis of gravity model, focused on labour force and the analysis of statistical data, we found mutually reinforcing correlations as well as ones contradicting each other. Our main findings are as follows:

- The extension of the gravity spaces - the complex one and the one only focused on labour market zones - suggests that the gravity zone of labour force increased compared to the complex gravity space especially in the case of settlements with smaller population.

- The model supports the assumption that the significance of commuting increased in the Hungarian economy between the two dates. Both the number of employees and the share of commuters within the employees increased. This growth can be traced in almost all segments (urban-rural relation, levels of the settlement hierarchy, etc.).

- There is now an increased role of settlements that are meso-level destinations of commuters, receiving 5,000-10,000 in-commuters daily. Both the number of in-commuters and the proportion of this settlement category increased.

- On the other hand, the share of larger cities (like Györ) in in-commuters decreased. Although there was a substantial increase in the number of in-commuters between the two

$7 \quad$ Rajka village is located along the Hungarian-Slovak border, in the direct proximity of the capital city of Slovakia. In the decade we examined the in-migration of Slovak citizens from Bratislava started, and now the proportion of them - according to certain calculations - exceeds half of the total population of Rajka, due to the residential suburbanisation process of the capital city of Slovakia. 
dates, the share of the centres still decreased. This is mainly due to the fact that a significant proportion of in-commuters arrive from the agglomerations or agglomerating areas around the large centres, and in these spaces important destinations of commuting have evolved in the recent years; what we can see in this case is a relative deconcentration.

- Parallel to this we can also see an absolute deconcentration, because a growing proportion of the population of larger centres also commute to work to other settlements or abroad. This statement is supported by the gravity space of the movements of labour force in Mosonmagyaróvár, ripping a substantial area off the gravity space of Györ.

- The findings of the region of North Transdanubia show a general tendency: in the direct proximity of several large centres a few employment centres started to develop, which reinforced relative deconcentration. This phenomenon is supported by the maps demonstrating the spaces of gravity: Szombathely has four small satellite gravity spaces, while the extended gravity zone of Györ is decreased by the gravity spaces of Pápa, Csorna and Kapuvár, in fact, as we have mentioned in the previous paragraph, of Mosonmagyaróvár.

- Outside the gravity areas of large centres, we can see a sort of concentration. As opposed to the vanishing or weakening of micro- and small centres, labour force now commutes to the larger centres in an increasing number. Depending on the transport possibilities, hierarchical relations appear: a growing number and share of the labour force of weakening regional centres commute to centres in higher position in the hierarchy, parallel to the increased share of in-commuters from nearby settlement within the labour force of the regional centres. At the same time, the gravity zones of small centres that have employment functions in the shade of large centres also grew in the ten years that we examined.

On the whole we can see the growing importance of economically more advanced regions in employment in rural areas and not only for the agglomeration, but also for more distant areas. This is shown by the gravity space of Györ calculated with the complex and the reduced weight, as this large city dominates in both cases the middle part of North Transdanubia from north to south. There is not one centre towards the western basin of the Lake Balaton that stops its action space, only smaller parts are ripped off by smaller centres. Smaller and middle-sized centres are alternatives for employment, and thereby for keeping the quality of life, and so their role in keeping the population in place is important.

It also became clear that we can distinguish two spatial types of commuting:

- Commuting between developed urban regions is not growing, which can be at least partially explained by the weakness of the horizontal transport infrastructure. It is more the hierarchical relations that are dominant among the settlements.

- At the same time, there are intensifying monocentric movements in rural areas around small and medium-sized centres, which is an indication of the growth in the number and proportion of forced commuters in these areas.

The gravity model proved to be a suitable tool for forecasting the catchment areas designated in an empirical way, by the amendment of the parameters of the model. 


\section{References}

Beluszky, P., 1966. Magyarország kereskedelmi központjai (Commerce centres in Hungary). Földrajzi Értesítő, 15, p. 237-251.

Benini, R., Naldi, P., 2007. RePUS Final Report. URL: http://www.espon-interstrat.eu/ admin/attachments/ZL_dsresource.pdf (Cited 20. 3. 2014).

Erlander, S., Stewart, N. F., 1990. The gravity model in transportation analysis - theory and extensions: topics in transportation. V S P International Science Publishers, $226 \mathrm{pp}$.

Greenwood, M. J., 2005. Modelling migration. In: Kempf-Leonard, K. (Ed.). Encyclopedia of social measurement, Volume 2, p. 725-734.

Győri, R., 1999. Térszerkezeti változások a polgárosodó Kisalföldön (Spatial structural changes in the Small Hungarian Plain in its bourgeois development). Tér és társadalom, 13, 4, p. 77-106.

Isard, W. et al., 1998. Methods of interregional and regional analysis. In: Gravity and spatial interaction models. Aldershot (U.K) and Brookfield (Vermont), Ashgate, p. 243-268.

Konrád, G., Szelényi, I., 2000. Urbanizáció és területi gazdálkodás (Urbanisation and spatial economy). Budapest, JGYF Kiadó, 135 pp.

KSH (Hungarian Central Statistical Office). Census of 2011. 2014. 8. Foglalkoztatás, munkanélküliség, ingázás (8. Employment, unemployment, commuting). Budapest. URL: http://www.ksh.hu/docs/hun/xftp/idoszaki/nepsz2011/nepsz_08_2011.pdf(Cited 20. 3. 2014).

Sikos, T. T. (Ed.), 1984. Matematikai és statisztikai módszerek alkalmazási lehetőségei a területi kutatásokban (Possible applications of mathematical and statistical methods in spatial researches). Földrajzi Tanulmányok, 19. Budapest, Akadémiai Kiadó, 301 pp.

Nagy, G., 1996. A gravitációs modell alkalmazási lehetőségei a településen belüli mozgások tanulmányozására (Possible applications of the gravity model for studying intra-urban spatial movements). Tér és társadalom, 10, 2-3, p. 149-156.

Pénzes, J., Molnár, E., Pálóczi, Á., 2014. Helyi munkaerőpiaci vonzáskörzetek az ezredforduló utáni Magyarországon (Local labour catchment areas in Hungary after the millennium). Területi statisztika, 5, p. 474-490.

Reilly, W. J.,1929. Methods for the study of retail relationships. University of Texas Bulletin, 2944, $50 \mathrm{pp}$.

Rodrigue, J. P., 2013. The geography of transport systems. 3rd edition. New York, Routledge, $416 \mathrm{pp}$.

Salamin, G., Radvánszky, Á., Nagy, A., 2008. A magyar településhálózat helyzete (Situation of the settlement network of Hungary). Falu Város Régió, 3, p. 6-25. 


\section{KOMPLEKSNE GRAVITACIJSKE CONE IN OBSEG MIGRACIJSKIH OBMOČIJ DELOVNE SILE V SEVERNI TRANSDANUBIJI, MADŽARSKA}

\section{Povzetek}

Članek se ukvarja z identifikacijo gravitacijskih središč v severni Transdanubiji (Madžarska), vključno z mestom Győr. Avtorja sta pri tem uporabila Reillyjev gravitacijski model in ga v naslednji fazi poskušala nadgraditi z določitvijo migracijskih območij delovne sile na osnovi ustreznih empiričnih ugotovitev (rezultati popisov 2001 in 2011). $\mathrm{Z}$ obema metodama sta določila vplivna območja urbanih središč in v nadaljevanju poskušala pojasniti, zakaj se vplivna območja, dobljena po obeh metodah, med seboj prekrivajo oziroma razlikujejo. V prispevku so pojasnjeni glavni geografski, socialni in ekonomski dejavniki, ki so verjetni razlogi za tovrstne razlike. Obe analizi sta bili opravljeni v dveh časovnih prerezih, med katerima je deset let časovne razlike.

Identifikacija vplivnih območij temelji na Reillyjevem gravitacijskem modelu, a smo pri preračunavanjih uporabili nekoliko spremenjeno verzijo modela - kot ponder smo uporabili izračunan (kompleksni) indikator. Medtem ko Reillyjev model opredeljuje mejo gravitacijskih območij med dvema točkama (mestoma), smo v našem modelu določili gravitacijska območja 31 naselij v severnem delu Transdanubije v dveh različnih časovnih presekih.

$\mathrm{V}$ drugem delu članka so predstavljene prostorske spremembe dnevne migracije $\mathrm{v}$ severni Transdanubiji. Osvetliti smo želeli tudi vlogo mesta in značilnosti gravitacijskega območja Győra v celotni regiji severna Transdanubija. V ta namen smo morali natančneje razmejiti območje dnevne migracije mesta Győr od gravitacijskih območij drugih zaposlitvenih središč v regiji. 